ZOOLOGIA 28 (4): 457-464, August, 2011

doi: $10.1590 /$ S1984-46702011000400007

\title{
Anurans from two high-elevation areas of Atlantic Forest in the state of Rio de Janeiro, Brazil
}

\author{
Carla C. Siqueiraㅁ; Davor Vrcibradic²; Thiago A. Dorigo ${ }^{3} \&$ Carlos F. D. Rocha ${ }^{3}$
}

\author{
1 Programa de Pós-Graduação em Ecologia, Instituto de Biologia, Universidade Federal do Rio de Janeiro. Avenida Carlos \\ Chagas Filho 373, Cidade Universitária, 21941-902 Rio de Janeiro, RJ, Brazil. E-mail: carlacsiqueira@yahoo.com.br \\ ${ }^{2}$ Departamento de Zoologia, Universidade Federal do Estado do Rio de Janeiro. Avenida Pasteur 458, Urca, 22240-290 Rio \\ de Janeiro, RJ, Brazil. \\ ${ }^{3}$ Departamento de Ecologia, Instituto de Biologia, Universidade do Estado do Rio de Janeiro. Rua São Francisco Xavier 524, \\ 20550-011 Rio de Janeiro, RJ, Brazil.
}

\begin{abstract}
The anurofauna inhabiting higher montane Atlantic forest areas in southeastern Brazil, which often attain heights of more than $2000 \mathrm{~m}$, is still insufficiently known. In this study, we present data on anuran species composition and abundances in two high-altitude (i.e. > 1000 m) sites within the Parque Estadual dos Três Picos (PETP), in the state of Rio de Janeiro. Field surveys were done at altitudes between 1100 and $1900 \mathrm{~m}$ above sea level. We recorded 35 species during our study, adding 22 records to the set of anuran species previously known to occur within the PETP. The stability of the species accumulation curve, as well as the richness estimations, showed that the sampling methodology employed and the total sampling effort were appropriate to inventory the anuran assemblages of both sites. Direct-developing frogs such as Ischnocnema parva (Girard, 1853) (at the 1100-1400 m altitude site), and Brachycephalus garbeanus Miranda-Ribeiro, 1920 (at the 1600-1900 m altitude site) were the most locally abundant species. None of the species recorded during the study is listed as threatened, though nine of them are currently considered endemic to the state of Rio de Janeiro. Furthermore, eight of the species recorded are likely restricted to high-altitude habitats. The relatively high diversity of anurans (some of them endemic to the state), the presence of species restricted to high-altitude habitats, and the occurrence of rare and presently undescribed species attest to the biological relevance of the studied areas within the PETP.
\end{abstract}

KEY WORDS. Altitude; amphibian; community; Serra dos Órgãos mountains; species richness.

Brazil has almost 900 species of anurans currently recorded (SBH 2010), corresponding to ca. 14\% of the world's anuran diversity (Araújo et al. 2009). One of the main Brazilian biomes, the Atlantic Rainforest, is one of the world's richest amphibian hotspots, housing ca. 400 species of anurans, with more than $80 \%$ of them considered endemic to this biome (CRUZ \& FeIo 2007). The state of Rio de Janeiro, despite its relatively small area (ca. $43,700 \mathrm{~km}^{2}$ ), contains a considerable proportion of Atlantic Rainforest anuran species, with relatively high rates of endemism (Rocha et al. 2004, VAN SLuYs et al. 2009). Rocha et al. (2004) listed 166 amphibian species for the state of Rio de Janeiro. Since then, several species have been added due to descriptions/revalidations of taxa (CARVAlHo-E-Silva \& Carvalho-e-Silva 2005, Canedo \& Pombal 2007, Pombal et al. 2008, Prado \& Pombal 2008, Silva \& Alves-Silva 2008, Carvalho-e-Silva et al. 2009, 2010, Targino et al. 2009, Pombal 2010, Weber et al. 2011) and to new occurrence records for the state (MARQUES et al. 2006, Vrcibradic et al. 2006, 2010, Pimenta et al. 2007, Carvalho-e-Silva et al. 2008, Silva-Soares et al. 2009, Silveira et al. 2009, CARAMASCH 2010), raising the list of amphibians to pres- ently 187 species. This number is likely to increase as further research on the state's anurofauna keeps advancing.

Preliminary lists of species of amphibians have been published for a number of areas in the state of Rio de Janeiro (Izecksohn \& Carvalho-e-Silva 2001a, b, Van Sluys et al. 2004, Almeida-Gomes et al. 2008, 2010, Carvalho-e-Silva et al. 2008, Silva et al. 2008, Salles et al. 2009, Silva-Soares et al. 2010), but those refer basically to low to mid-elevation (up to ca. $1000 \mathrm{~m}$ ) areas. Although the two main mountain ranges in eastern Brazil, the Serra do Mar and the Serra da Mantiqueira, occasionally attain heights of more than $2000 \mathrm{~m}$ in the state of Rio de Janeiro, knowledge of the anurofauna inhabiting higher montane areas in the state is still insufficient. The most comprehensive work to date is the revision of CRUz \& FeIo (2007), who listed the anuran species endemic to the higher portions of the aforementioned mountain ranges in southeastern Brazil.

Despite intense deforestation, the state of Rio de Janeiro still has proportionately large forested areas, most of them along the Serra do Mar mountain range (Rocha et al. 2003). The central portion of the Serra do Mar in Rio de Janeiro receives the 
regional denomination of Serra dos Órgãos, and is renowned by its remarkable biodiversity and rates of endemism, particularly regarding the fauna (Rocha et al. 2003, Cruz \& FeIo 2007). The Parque Estadual dos Três Picos (hereafter PETP), with a total area of more than 46,000 ha, represents one of the state's most extensive continuous areas of Atlantic Rainforest contained within a Conservation Unit (Rосна et al. 2003). It contains some of the highest peaks of the Serra dos Órgãos mountain range, often exceeding $2000 \mathrm{~m}$ in altitude. Two recent studies have been carried out on anuran assemblages within this Park, both dealing specifically with the leaf-litter anuran guild: one was carried out at altitudes up to $400 \mathrm{~m}$ (Rосна et al. 2007) and the other at altitudes between 500 and $800 \mathrm{~m}$ (Siqueira et al. 2009). Here, we present data on anuran species composition and abundance in two high-altitude areas (above $1000 \mathrm{~m}$ high) within the Parque Estadual dos Três Picos and discuss the species richness recorded at each site, as well as the species showing restricted endemism. The list of anurans presented herein represents the continuation of our efforts to investigate the anuran assemblages on the Atlantic Forests of the state of Rio de Janeiro, aiming to contribute toward their conservation.

\section{MATERIAL AND METHODS}

The Parque Estadual dos Três Picos (hereafter PETP) is a conservation unit that is co-extensive with most of the Serra dos Órgãos mountain range, and encompasses portions of five municipalities in the state of Rio de Janeiro, southeastern Brazil. The study was carried out in two adjacent mountains located inside the PETP, in the municipality of Nova Friburgo: one in Theodoro de Oliveira district $\left(22^{\circ} 21^{\prime} 59^{\prime \prime}-22^{\circ} 22^{\prime} 23^{\prime \prime} \mathrm{S}\right.$, $42^{\circ} 33^{\prime} 16^{\prime \prime}-42^{\circ} 33^{\prime} 31^{\prime \prime} \mathrm{W}$ ) and the other in an area locally known as Baixo Caledônia $\left(22^{\circ} 21^{\prime} 34^{\prime \prime} \mathrm{S}, 42^{\circ} 34^{\prime} 04^{\prime \prime}-42^{\circ} 34^{\prime} 25^{\prime \prime} \mathrm{W}\right)$, on the Caledônia mountain (one of the highest in the Serra dos Órgãos, reaching over $2200 \mathrm{~m}$ at its peak). Vegetation at Theodoro de Oliveira consists of Dense Ombrophilous Montane Forest, whereas at Baixo Caledônia it ranges from High Montane Forest at the lower portion to Montane Fields ("campos de altitude"; see EITEN 1992) at the higher portion (IBGE 1992). At the Theodoro de Oliveira site there is a greater availability of water bodies (mainly rocky streams) when compared to Baixo Caledônia. In this latter locality, the terrain is quite steep over much of the forested portions, whose vegetation is more dense and with a lower canopy compared to the Theodoro de Oliveira site. Annual rainfall in the general area is about 1,700-2,300 $\mathrm{mm}$ and the mean annual temperature is ca. $18^{\circ} \mathrm{C}$. The climate in the region is seasonal, with a dry/cool season from May to September and a wet/warm season from November to March (INEA 2009).

Surveys were carried out in March, July and August 2008, in February, March, August and September 2009, and in January and March 2010, at altitudes between 1100 and $1400 \mathrm{~m}$ at Theodoro de Oliveira, and between 1600 and $1900 \mathrm{~m}$ at Baixo
Caledônia. We sampled during months of both the wet/warm (January-March) and dry/cool (July-September) seasons to account for possible seasonal variations in activity of different frog species. Samplings of anurans were always done at night, using an adaptation of the time-constrained visual encounter survey method (CRUMP \& SCOTT 1994). The number of observers at each survey episode (i.e. month) was usually five. Sampling effort totaled 180 hours of active search in wet season months and 120 hours in dry season months at Theodoro de Oliveira, and 60 hours in wet season months and 40 hours in dry season months at Baixo Caledônia. Thus, we performed a total of 300 hours of searches at Theodoro de Oliveira, and of 100 hours at Baixo Caledônia. We worked fewer hours at Baixo Caledônia because it was harder to move around in this area due to the structure of the vegetation and the steep terrain, and because the total area available for searching was smaller.

All frogs found were captured, identified and most were released after fieldwork. Besides, all individuals found during casual encounters (i.e. outside the sampling period) were also recorded, though not included in the estimates of relative abundances. Voucher specimens of all frog species recorded during the study, with the exception of Hypsiboas faber (Wied-Neuwied, 1821) and Rhinella icterica (Spix, 1824), were deposited at the Museu Nacional, Rio de Janeiro (see Appendix).

The evaluation of collection effectiveness (from VES method) was undertaken by a species accumulation curve (collector curve) and a rarefaction curve. The latter was done using an estimator (Bootstrap) performing 1,000 randomizations without replacement, using the program EstimateS 8.2.0 (Colwell 2005).

\section{RESULTS}

We recorded a total of 35 species of anurans in the present study, with 31 species recorded at Theodoro de Oliveira and nine species at Baixo Caledônia (Tab. I). The species accumulation curves and the rarefaction curves showed a clear asymptotic shape, with a tendency to reaching stability (Figs 1 and 2). Also, our estimates of frog richness for both sites $(26.5 \pm 0.2$ species at Theodoro de Oliveira and $10.1 \pm 0.4$ species at Baixo Caledônia) were close to the richness values (25 and eight species, respectively) obtained by us with visual encounter surveys.

The most abundant species were Ischnocnema parva (Girard, 1853) at Theodoro de Oliveira (comprising 62\% of all individuals recorded there), and Brachycephalus garbeanus Miranda-Ribeiro, 1920 (93\%) at Baixo Caledônia (Tab. I). The most specious anuran families at the studied areas were Hylidae (11 species) and Brachycephalidae (8 species) at Theodoro de Oliveira, and Brachycephalidae (4 species) at Baixo Caledônia (Tab. I). Among the species recorded during the study, ten (excluding the undescribed ones) are currently considered endemic to the state of Rio de Janeiro and 22 represent new records for the PETP (Tab. I). 

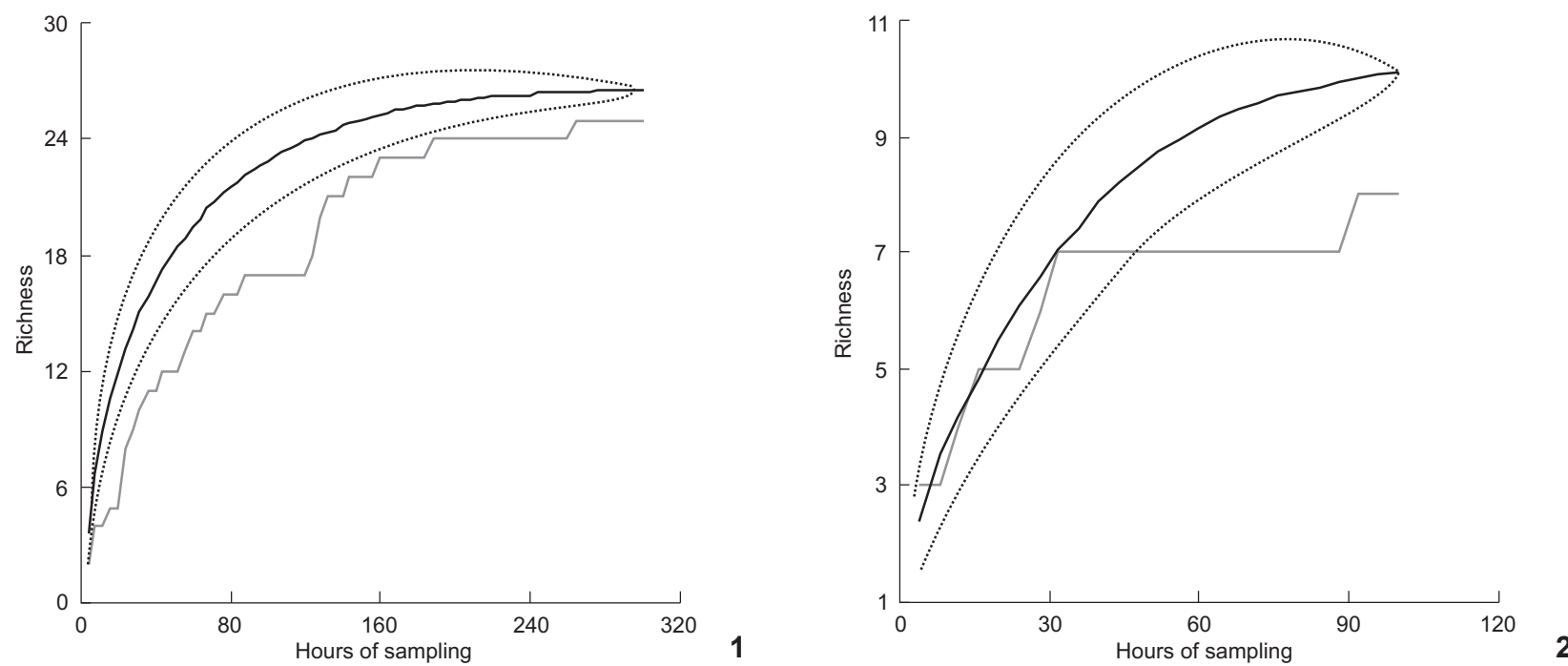

Figures 1-2. Cumulative curves of species (gray solid line), and richness estimators (black solid line), with the respective standard deviation (dashed lines), of anurans recorded in the Atlantic Rainforest areas of Theodoro de Oliveira (1) and Baixo Caledônia (2), within the Parque Estadual dos Três Picos, in Rio de Janeiro State, Brazil.

Seven species (six at Theodoro de Oliveira and one at Baixo Caledônia) were found only during occasional encounters). Among them, five hylids $-H$. faber, Hypsiboas polytaenius (Cope, 1870), Dendropsophus minutus (Peters, 1872), Scinax fuscovarius (Lutz, 1925) and $S$. cf. perereca - were found only in open/anthropically disturbed habitats, whereas Gastrotheca albolineata (Lutz \& Lutz, 1939) was found at a forested area, and Rhinella gr. crucifer was found both within the forest and in open areas. Rhinella icterica, though also found during "visual encounter surveys" within the forest, was found much more frequently during casual encounters in open, disturbed habitats.

\section{DISCUSSION}

Based on the comparatively few studies reporting anuran species from areas within the PEPT (RocHA et al. 2007, WEBer et al. 2007, 2009, Роmbal et al. 2008, Siqueira et al. 2009, Pombal 2010), 26 anuran species are presently reported for areas within that State Park, all at low to mid-elevations. The present study, carried out at high-elevation areas, raise the current anuran list for the PETP to 48 species, by adding 22 records. Considering the vast area of the PETP (over 46,000 ha), its considerable altitudinal range and habitat heterogeneity, and the fact that most of it remains poorly studied regarding its anurofauna, we believe that 48 species is still a gross underestimate of the anuran diversity contained within the Park's limits. Moreover, at least ten of the 35 species recorded by us at the study sites (ca. 29\% of the total) are currently considered endemic to the state of Rio de Janeiro.
The tendency for stability of the species accumulation and rarefaction curves, as well as the richness estimations, showed that the sampling methodology employed and the total sampling effort were appropriate to inventory the local anuran assemblages (even considering the large difference in number of sampling hours between the two sites). Species richness values (both estimated and observed) for Theodoro de Oliveira were about three times higher than for Baixo Caledônia. This may be a consequence of distinct environmental conditions between the two sites, as a result of their altitudinal differences. Some previous studies on anuran assemblages in tropical forests have shown a tendency for species richness to be lower at higher elevations (e.g., Brown \& Alcala 1961, Scott 1976, Fauth et al. 1989), as observed in our study. The Baixo Caledônia site presents harsher conditions (e.g., lower mean and minimum temperatures, wider daily thermal variations, more reduced availability of free water, greater exposure to wind; INEA 2009, pers. obs.) compared to the Theodoro de Oliveira site. Such conditions could be limiting to a number of species, preventing their occurrence at the higher site (see NAvAS 2003), though this has not been tested in the present study. Additionally, the lower species richness at Baixo Caledônia may also reflect the smaller area available for sampling at that locality.

The brachycephalids $I$. parva (at Theodoro de Oliveira; 1100-1400 m altitude), and B. garbeanus (at Baixo Caledônia; 1600-1900 m altitude) were the most locally abundant species found during our study. In previous studies carried out in other areas within the PETP, the most abundant species were also direct developers: Euparkerella brasiliensis (Parker, 1926) (Strabomantidae) at a mid-elevation (500-800 m) area (SIQUeIRA et al. 
Table I. List of anuran species occurring in the Atlantic Rainforest areas of Theodoro de Oliveira (TO) and Baixo Caledônia (BC), within the Parque Estadual dos Três Picos (PETP), in Rio de Janeiro State, Brazil. Abundance is given for each species in each area as absolute values and percentages (in parentheses). The species endemic to the state (RJ) are indicated with an " $X$ ". Species that have been recorded only during occasional encounters are indicated by "OE" and were not quantified. Species that have not been previously reported for the PETP are marked with asterisks $(*)$.

\begin{tabular}{|c|c|c|c|}
\hline \multirow{2}{*}{ Species } & \multicolumn{2}{|l|}{ Abundance (\%) } & \multirow{2}{*}{ Endemic } \\
\hline & TO & $\mathrm{BC}$ & \\
\hline \multicolumn{4}{|l|}{ Bufonidae } \\
\hline Dendrophriniscus cf. brevipollicatus* & & $4(1.5)$ & \\
\hline Rhinella icterica (Spix, 1824) & $4(0.4)$ & & \\
\hline Rhinella gr. crucifer & $\mathrm{OE}$ & & \\
\hline \multicolumn{4}{|l|}{ Brachycephalidae } \\
\hline Brachycephalus didactylus (Izecksohn, 1971) & $3(0.3)$ & & $x$ \\
\hline Brachycephalus garbeanus Miranda-Ribeiro, 1920 & $2(0.2)$ & $247(92.9)$ & $x$ \\
\hline Brachycephalus sp.* & $17(1.8)$ & & $x$ \\
\hline Ischnocnema erythromera (Heyer, 1984)* & $103(11.0)$ & & $x$ \\
\hline Ischnocnema guentheri (Steindachner, 1864) & $6(0.6)$ & $4(1.5)$ & \\
\hline Ischnocnema cf. holti* & $6(0.6)$ & $3(1.1)$ & $x$ \\
\hline Ischnocnema parva (Girard, 1853) & $577(61.6)$ & $3(1.1)$ & \\
\hline Ischnocnema sp. (gr. lactea)* & $4(0.4)$ & & $?$ \\
\hline \multicolumn{4}{|l|}{ Craugastoridae } \\
\hline Haddadus binotatus (Spix, 1824) & $6(0.6)$ & & \\
\hline \multicolumn{4}{|l|}{ Cycloramphidae } \\
\hline Proceratophrys boiei (Wied-Neuwied, 1824) & $2(0.2)$ & & \\
\hline Proceratophrys melanopogon (Miranda-Ribeiro, 1926)* & $39(4.2)$ & $1(0.4)$ & \\
\hline Zachaenus parvulus (Girard, 1853) & $32(3.4)$ & & \\
\hline \multicolumn{4}{|l|}{ Hemiphractidae } \\
\hline Flectonotus fissilis* & $2(0.2)$ & & \\
\hline Flectonotus sp.* & & $3(1.1)$ & $?$ \\
\hline Gastrotheca albolineata (Lutz \& Lutz, 1939)* & $\mathrm{OE}$ & & \\
\hline Gastrotheca ernestoi Miranda-Ribeiro, 1920* & & $1(0.4)$ & $x$ \\
\hline \multicolumn{4}{|l|}{ Hylidae } \\
\hline Aplastodiscus arildae (Cruz \& Peixoto, 1987)* & $3(0.3)$ & & \\
\hline Aplastodiscus leucopygius (Cruz \& Peixoto, 1985)* & $6(0.6)$ & & \\
\hline Bokermannohyla carvalhoi (Peixoto, 1981)* & $10(1.1)$ & & $x$ \\
\hline Bokermannohyla circumdata (Cope, 1871)* & $11(1.2)$ & & \\
\hline Dendropsophus minutus (Peters, 1872) * & OE & & \\
\hline Hypsiboas faber (Wied-Neuwied, 1821)* & $\mathrm{OE}$ & & \\
\hline Hypsiboas polytaenius (Cope, 1870)* & $\mathrm{OE}$ & & \\
\hline Scinax albicans (Bokermann, 1967) & $8(0.9)$ & & $x$ \\
\hline Scinax flavoguttatus (Lutz \& Lutz, 1939)* & $12(1.3)$ & & \\
\hline Scinax fuscovarius (Lutz, 1925)* & & OE & \\
\hline Scinax cf. obtriangulatus* & $1(0.1)$ & & \\
\hline Scinax cf. perereca & OE & & $?$ \\
\hline Scinax v-signatus (Lutz, 1968)* & $13(1.4)$ & & \\
\hline \multicolumn{4}{|l|}{ Hylodidae } \\
\hline Hylodes charadranaetes Heyer \& Cocroft, 1986 & $60(6.4)$ & & $x$ \\
\hline \multicolumn{4}{|l|}{ Microhylidae } \\
\hline Myersiella microps (Duméril \& Bibron, 1841) & $5(0.5)$ & & \\
\hline \multicolumn{4}{|l|}{ Strabomantidae } \\
\hline Holoaden pholeter Pombal, Siqueira, Dorigo, Vrcibradic \& Rocha, 2008 & $4(0.4)$ & & $x$ \\
\hline Total & $936(100.0)$ & $266(100.0)$ & \\
\hline
\end{tabular}


2009), and Ischnocnema guentheri (Steindachner, 1864) at low altitudes (up to $400 \mathrm{~m}$ ) (Roche et al. 2007). Individuals of species with direct development and terrestrial eggs (Terrarana sensu Hedges et al. 2008) thus appear to numerically dominate the anuran assemblages at the PETP (irrespective of altitude), as has been observed in most studied Neotropical litter frog assemblages (e.g., Scott 1976, Lieberman 1986, Fauth et al. 1989, Giaretta et al. 1997, 1999, Rocha et al. 2001).

Hylodes charadranaetes Heyer \& Cocroft, 1986, which was quite abundant at Theodoro de Oliveira, was the only strictly reophilic (stream-adapted) species found in our study. At night those frogs were always found inactive, mainly perched on vegetation at the margins of rocky streams, whereas during the day we heard (and occasionally sighted) calling males on rocks along the streams. Thus, the conservation of this type of environment is crucial for the permanence of the local population of this species. Hylodids, in general, can be considered as good indicators of habitat quality in forest environments, as they are dependent of lotic streams with clean water (VAN SLuYs et al. 2009).

Cruz \& Feio (2007) listed 11 species they considered as endemic to highland areas in the Serra dos Órgãos region. However, two of them ( $G$. albolineata and $H$. charadranaetes) have since been shown to range down to low altitudes and to occur outside the Serra dos Órgãos region (CARVALHO-E-Silva et al. 2008, Gressler et al. 2008, VRCibradic et al. 2008). In the present study, besides the two aforementioned species, we recorded two other - Ischnocnema erythromera (Heyer, 1984) and Bokermannohyla carvalhoi (Peixoto, 1981) - that are also in the list of CRUz \& Feio (2007). Holoaden pholeter Pombal, Siqueira, Dorigo, Vrcibradic \& Rocha, 2008, a species recently described based on specimens collected during the present study, can also be added to that list. Also, B. garbeanus, which has recently been removed from the synonymy of Brachycephalus ephippium (Spix, 1824) by PомваL (2010), is apparently another endemic of the Serra dos Órgãos mountains. Another species recorded in our study - Gastrotheca ernestoi Miranda-Ribeiro, 1920, a taxon recently revalidated by CARAMASCHI \& Rodrigues (2007) -, though not endemic to the Serra dos Órgãos, is also probably restricted to high elevation areas in the mountains of southeastern Brazil. This is apparently the case for some of the other species found, such as Aplastodiscus leucopygius (Cruz \& Peixoto, 1985), Proceratophrys melanopogon (Miranda-Ribeiro, 1926), and Scinax cf. obtriangulatus (Cruz \& FeIo 2007). Nevertheless, most of the species recorded in this study have wide altitudinal ranges, also occurring at mid- and low elevations - e.g., Bokermannohyla circumdata (Cope, 1871), D. minutus, H. faber, G. albolineata, Haddadus binotatus (Spix, 1824), H. charadranaetes, I. parva, Proceratophrys boiei (Wied-Neuwied, 1824), R. icterica, R. gr. crucifer, Scinax albicans (Bokermann, 1967), Scinax flavoguttatus (Lutz \& Lutz, 1939), S. fuscovarius.

None of the species recorded by us in the present study (not counting the currently undescribed and the taxonomically problematic ones; see below) is considered as threatened with extinction at either a state-wide (CARAMASCHI et al. 2000), a country-wide (MACHADo et al. 2008), or a global scale (IUCN 2010). Holoaden pholeter, known only from the type locality in Theodoro de Oliveira (Pombal et al. 2008), is presently considered as "Data Deficient" by the IUCN (2010). At present, even after many hours of searches for frogs at that locality, only four individuals of this species (including the three that comprise the type series) have been found so far, which suggests us that this is a locally rare species. Because of its restricted geographic distribution and probably low population density, we believe that $H$. pholeter may be a candidate for inclusion in the "vulnerable" category of the IUCN red list of threatened species.

Though taxonomic issues are outside the scope of the present study, it is worth mentioning that some of the specimens collected by us represent new or presumably new taxa. Brachycephalus sp., found by us at Theodoro de Oliveira, is a previously unknown member of the genus and is currently in the process of being formally described. The specimens referred as Flectonotus sp. may also represent a currently undescribed taxon, and what we treat here as Ischnocnema cf. holti is possibly a taxon distinct from I. holti (Cochran, 1948) (M. Targino and C. Canedo, pers. comm.). Four small specimens of an indeterminate species of Ischnocnema of the lactea group collected at Theodoro de Oliveira may also possibly represent a new taxon (C. Canedo, pers. comm.). Additionally, Dendrophriniscus brevipollicatus Jiménez de la Espada, 1870 and Scinax perereca Pombal, Haddad \& Kasahara, 1995 may represent species complexes, and the actual taxonomic status of the specimens collected during the present study may only be defined after a careful systematic revision (C.A.G. Cruz and J.P. Pombal Jr, pers. comm.). This considerable number of potentially new taxa found during our study is in turn suggestive of a high gammadiversity at the PEPT. In fact, the few other studies providing information on the anurofauna of the Park (Rocha et al. 2007, Weber et al. 2007, 2009, Pombal et al. 2008, Siqueira et al. 2009) were performed in other sites, and the two areas we surveyed in the present study had not been previously searched for frogs.

As pointed out by CRUz \& FEIO (2007), the fauna of Atlantic Forest amphibians living at high altitudes is still insufficiently known. Our inventory is a contribution to the knowledge on the amphibian fauna of high-elevation forests in an area that is still poorly studied, with scattered information on the diversity and composition of frog assemblages. The fact that new species have been discovered at Theodoro de Oliveira during our fieldwork (including the recently described $H$. pholeter) reinforces this idea. We believe that the relatively high anuran richness (considering the relatively small area surveyed), the presence of species restricted to high-altitude habitats (including a few endemics of the Serra dos Órgãos region), and the occurrence of rare and of currently undescribed species makes Theodoro de Oliveira an area of great biodiversity relevance within the PETP. 


\section{ACKNOWLEDGEMENTS}

We thank the Instituto Estadual do Ambiente (INEA) for the permission for working at the Parque Estadual dos Três Picos (PETP). We thank Adriano Luz from PETP, and Moisés and Tânia Vasconcelos from Pousada Vale dos Sonhos for making facilities available and for local support. Carlos Frederico D. Rocha received resources from the Conselho Nacional de Desenvolvimento Científico e Tecnológico (CNPq processes 304791/2010-5 and 470265/2010-8) and from the Fundação de Amparo à Pesquisa do Estado do Rio de Janeiro (FAPERJ process E-26/ 102.404/2009) through the program Cientistas do Nosso Estado. This project also beneffited from funding of the Edital Espécies Ameaçadas of Fundação Biodiversitas/CEPAN and RAN/ICMBio (Project 0158A/012006). During this study C.C. Siqueira received a PhD grant from the CNPq. and T.A. Dorigo received a graduate fellowship from the Coordenação de Aperfeiçoamento de Pessoal de Nível Superior (CAPES). We also thank J.P. Pombal Jr, C. Canedo, C.A.G. Cruz, A.C.C. Lourenço, I. Nunes and M. Targino for helping us with the identification of the amphibians.

\section{LITERATURE CITED}

Almeida-Gomes, M.; D. Vrcibradic; C.C. Siqueira; M.C. Kiefer; T. Klaion; P. Almeida-Santos; D. Nascimento; C.V. Ariani; V.N.T. Borges-Junior; R.F. Freitas-Filho; M. Van Sluys \& C.F.D. RoCHA. 2008. Herpetofauna of an Atlantic Rainforest area (Morro São João) in Rio de Janeiro State, Brazil. Anais da Academia Brasileira de Ciências 80 (2): 291-300.

Almeida-Gomes, M.; M. Almeida-Santos; P. Goyannes-Araújo; V.N.T. Borges-Júnior; D. Vrcibradic; C.C. Siqueira; C.V. Ariani; A.S. Dias; V.V. Souza; R.R. Pinto; M. Van Sluys \& C.F.D. Rocha. 2010. Anurofauna of an Atlantic Rainforest fragment and its surroundings in northern Rio de Janeiro State, Brazil. Brazilian Journal of Biology 70 (Suppl.): 871-877.

Araújo, O.G.S.; L.F. Toledo; P.C.A. Garcia \& C.F.B. Haddad. 2009. The amphibians of São Paulo State, Brazil. Biota Neotropica 9 (4): 1-13.

Brown, W.C. \& A.C. Alcala. 1961. Populations of amphibians and reptiles in the submontane and montane forests of Cuernos de Negros, Philippine Islands. Ecology 42 (4): 628636.

Canedo, C. \& J.P. Pombal JR. 2007. Two new species of torrent frog of the genus Hylodes (Anura, Hylodidae) with nuptial thumb tubercles. Herpetologica 63 (2): 224-235.

Caramaschi, U. 2010. Notes on the taxonomic status of Elachistocleis ovalis (Schneider, 1799) and description of five new species of Elachistocleis Parker, 1927 (Amphibia, Anura, Microhylidae). Boletim do Museu Nacional (Zoologia) 527: 130.

Caramaschi, U. \& M.T. Rodrigues. 2007. Taxonomic status of the species of Gastrotheca Fitzinger, 1843 (Amphibia, Anura, Amphignathodontidae) of the Atlantic rain forest of eastern
Brazil, with description of a new species. Boletim do Museu Nacional, Sér. Zoologia, 525: 1-19.

Caramaschi, U.; A.M.P.T. Carvalho-e-Silva; S.P. Carvalho-e-Silva; E. Gouvêa; E. Izecksohn; O.L. Реixoto \& J.P. Pombal Jr. 2000. Anfíbios, p. 75-78. In: H.G. Bergallo; C.F.D. Rocha; M.A.S. Alves \& M. Van Sluys (Eds). A Fauna Ameaçada de Extinção do Estado do Rio de Janeiro. Rio de Janeiro, EdUERJ, 166p.

Carvalho-e-Silva, A.M.P.T. \& S.P. Carvalho-e-Silva. 2005. New species of the Hyla albofrenata group, from the States of Rio de Janeiro and São Paulo, Brazil (Anura, Hylidae). Journal of Herpetology 39 (1): 73-81.

Carvalho-e-Silva, A.M.P.T.; G.R. Silva \& S.P. Carvalho-e-Silva. 2008. Anuros da Reserva Rio das Pedras, Mangaratiba, RJ, Brasil. Biota Neotropica 8 (1): 199-209.

Carvalho-e-Silva, A.M.P.T.; G.R. Silva \& S.P. Carvalho-e-Silva. 2009. A new species of Phasmahyla Cruz, 1990 from the Atlantic Forest in the state of Rio de Janeiro, Brazil (Amphibia, Hylidae, Phyllomedusinae). Zootaxa 2120: 15-26.

Carvalho-e-Silva, A.M.P.T.; M.M. Mongin; E. Izecksohn \& S.P. Carvalho-e-Silva. 2010. A new species of Dendrophryniscus Jiménez-de-la-Espada from the Parque Nacional da Serra dos Órgãos, Teresópolis, State of Rio de Janeiro, Brazil (Amphibia, Anura, Bufonidae). Zootaxa 2632: 46-52.

Colwell, R.K. 2005. Estimates: statistical estimation of species richness and shared species from samples. Version 8.2. User's Guide and application available online at: http:// viceroy.eeb.uconn.edu/estimates [Accessed: 09/IV/2010].

Crump, M.L. \& N.J. Scott Jr. 1994. Visual encounter surveys, p. 84-92. In: W.R. Heyer; M.A. Donnelly; R.W. McDiarmid; L.A.C. HAyeK \& M.S. Foster (Eds). Measuring and Monitoring Biological Diversity: Standard Methods for Amphibians. Washington, DC, Smithsonian Institution Press, 364p.

Cruz, C.A.G. \& R.N. Feio. 2007. Endemismos em anfíbios em áreas de altitude na Mata Atlântica no sudeste do Brasil, p. 117-126. In: L.B. Nascimento \& M.E. Oliveira (Eds). Herpetologia no Brasil II. Belo Horizonte, Sociedade Brasileira de Herpetologia, 354p.

Eiten, G. 1992. Natural Brazilian vegetation types and their causes. Anais da Academia Brasileira de Ciências 64 (Suppl. 1): 35-65.

Fauth, J.E.; B.I. Crother \& J.B. Slowinski. 1989. Elevational patterns of species richness, evenness and abundance of the Costa Rican leaf-litter herpetofauna. Biotropica 21 (2): 178-185.

Giaretta, A.A.; R.J. Sawaya; G. Machado; M.S. Araújo; K.G. Facure; H.F. Medeiros \& R. Nunes. 1997. Diversity and abundance of litter frogs at altitudinal sites at Serra do Japi, Southeastern Brazil. Revista Brasileira de Zoologia 14 (2): 341-346.

Giaretta, A.A.; K.G. Facure; R.J. Sawaya; J.H.D. Meyer \& N. Chemin. 1999. Diversity and abundance of litter frogs in a montane forest of southeastern Brazil: seasonal and altitudinal changes. Biotropica 31 (4): 669-674.

Gressler, E.; A.G. Aguirre \& C.F.B. Haddad. 2008. Amphibia, Anura, Amphignathodontidae, Gastrotheca albolineata: 
Distribution extension, new state, and new altitudinal records. Check List 4 (1): 31-32.

Hedges, S.B.; W.E. Duellman \& M.P. Heinicke. 2008. New world direct-developing frogs (Anura: Terrarana): molecular phylogeny, classification, biogeography, and conservation. Zootaxa 1737: 1-182.

IBGE. 1992. Manual Técnico da Vegetação Brasileira. Rio de Janeiro, Fundação Instituto Brasileiro de Geografia e Estatística, Departamento de Recursos Naturais e Ambientais, 92p.

INEA. 2009. Plano de Manejo do Parque Estadual dos Três Picos. Rio de Janeiro, Instituto Estadual do Ambiente, 655p.

IUCN. 2010. The IUCN Red List of Threatened Species (version 2010.1). Available online at: http://www.iucnredlist.org. [Accessed: 09/IV/2010].

Izecrsohn, E. \& S.P. CARVAlHo-e-Silva. 2001a. Anfíbios do Município do Rio de Janeiro. Rio de Janeiro, Editora da Universidade Federal do Rio de Janeiro, 147p.

Izecksohn, E. \& S.P. Carvalho-e-Silva. 2001b. Anfíbios da Floresta Nacional Mário Xavier, município de Seropédica, estado do Rio de Janeiro, Brasil (Amphibia: Anura). Contribuições Avulsas Sobre a História Natural do Brasil 39: 1-3.

Lieberman, S.S. 1986. Ecology of the leaf litter herpetofauna of a Neotropical rainforest: La Selva, Costa Rica. Acta Zoologica Mexicana 15 (1): 1-71.

Machado, A.B.M.; G.M. Drummond \& A.P. Paglia. 2008. Livro Vermelho da Fauna Brasileira Ameaçada de Extinção. Belo Horizonte, Fundação Biodiversitas, vol. 2, 907p.

Marques, F.A.; B.B. Annunziata,; A.M.P.T. Carvalho-e-Silva. 2006. Geographic Distribution. Bufo crucifer. Herpetological Review 37 (1): 98.

NAVAS C.A. 2003. Herpetological diversity along Andean elevational gradients: links with physiological ecology and evolutionary physiology. Comparative Biochemistry and Physiology 133: 469-485.

Pimenta, B.V.S.; R.S. Bérnils \& J.P. Pombal JR. 2007. Amphibia, Anura, Brachycephalidae, Brachycephalus hermogenesi: Filling gap and geographic distribution map. Check List 3 (3): 277-279.

Pombal JR, J.P. 2010. A posição taxonômica das "variedades" de Brachycephalus ephippium (Spix, 1824) descritas por MirandaRibeiro, 1920 (Amphibia, Anura, Brachycephalidae). Boletim do Museu Nacional, Zoologia, 526: 1-12.

Pombal JR, J.P.; C.C. Siqueira; T.A. Dorigo; D. Vrcibradic \& C.F.D. Rocha. 2008. A third species of the rare frog genus Holoaden (Terrarana, Strabomantidae) from a montane rainforest area of southeastern Brazil. Zootaxa 1938: 61-68.

Prado, G.M. \& J.P. Pombal Jr. 2008. Espécies de Proceratophrys Miranda-Ribeiro, 1920 com apêndices palpebrais (Anura; Cycloramphidae). Arquivos de Zoologia 39 (1): 1-85.

Rocha, C.F.D.; M. Van Sluys; M.A.S. Alves; H.G. Bergallo \& D. VRcibradic. 2001. Estimates of forest floor litter frog communities: a comparison of two methods. Austral Ecology 26 (1): 14-21.

Rocha, C.F.D.; H.G. Bergallo; M.A.S. Alves \& M. Van SluYs. 2003.
A Biodiversidade nos Grandes Remanescentes Florestais do Estado do Rio de Janeiro e nas Restingas da Mata Atlântica. São Carlos, RiMa, 160p.

Rocha, C.F.D.; H.G. Bergallo; J.P. Pombal Jr; L. Geise; M. Van Sluys; R. Fernandes \& U. Caramaschi. 2004. Fauna de anfíbios, répteis e mamíferos do Estado do Rio de Janeiro, sudeste do Brasil. Publicações Avulsas do Museu Nacional 104: 3-23.

Rocha, C.F.D.; D. Vrcibradic; M. C. Kiefer; M. Almeida-Gomes; V.N.T. Borges-Jr; P.C.F. Carneiro; R.V. Marra; P. Almeida-Santos; C.C. Siqueira; P. Goyannes-Araújo; C.G.A. Fernandes; E.C.N. Rubiño \& M. VAN Sluys. 2007. A survey of the leaf-litter frog assembly from an Atlantic Forest area (Reserva Ecológica de Guapiaçu) in Rio de Janeiro State, Brasil, with an estimate of frog densities. Tropical Zoology 20 (1): 99-108.

Salles, R.O.L.; L.N. Weber \& T. Silva-Soares. 2009. Amphibia, Anura, Parque Natural Municipal da Taquara, municipality of Duque de Caxias, state of Rio de Janeiro, southeastern Brazil. Check List 5 (4): 840-854.

Silveira, A.L.; R.O.L. Salles \& R.C. Pontes. 2009. Primeiro registro de Rhinella pombali e novos registros de R. crucifer e $R$. ornata no Estado do Rio de Janeiro, Brasil (Amphibia, Anura, Bufonidae). Biotemas 22 (4): 231-235.

SBH. 2010. Brazilian amphibians - List of species. Available online at http://www.sbherpetologia.org.br. Sociedade Brasileira de Herpetologia [Accessed: 31/III/2010].

Scott JR, N.J. 1976. The abundance and diversity of the herpetofauna of tropical forest litter. Biotropica 8 (1): 41-58.

Silva, H.R. \& R. Alves-Silva. 2008. New coastal and insular species of the bromeligenous Scinax perpusillus group, from the State of Rio de Janeiro, Brazil (Anura, Hylidae). Zootaxa 1914: $34-44$.

Silva, H.R.; A.L.G. Carvalho \& G.B. Bittencourt-Silva. 2008. Frogs of Marambaia: a naturally isolated Restinga and Atlantic Forest remnant of southeastern Brazil. Biota Neotropica 8 (4): $167-174$.

Silva-Soares, T.; R.B. Ferreira \& P.N. Costa. 2009. Geographic Distribution. Ischnocnema oea. Herpetological Review 40 (1): 108-109.

Silva-Soares, T.; F. Hepp; P.N. Costa; C. Luna-Dias; M.R. Gomes; A.M.P.T. Carvalho-e-Silva \& S.P. Carvalho-e-Silva. 2010. Anfibios anuros da RPPN Campo Escoteiro Geraldo Hugo Nunes, Município de Guapimirim, Rio de Janeiro, sudeste do Brasil. Biota Neopropica 10 (2): 225-233.

Silveira, A.L.; R.O.L. Salles \& R.C. Pontes. 2009. Primeiro registro de Rhinella pombali e novos registros de R. crucifer e $R$. ornata no Estado do Rio de Janeiro, Brasil (Amphibia, Anura, Bufonidae). Biotemas 22 (4): 231-235.

Siqueira, C.C.; D. Vrcibradic; M. Almeida-Gomes; V.N.T. BorgesJr; P. Almeida-Santos; M. Almeida-Santos; C.V. Ariani; D.M. Guedes; P. Goyannes-Araújo; T.A. Dorigo; M. Van Sluys \& C.F.D. Rосна. 2009. Density and richness of the leaf litter frogs of an Atlantic Rainforest area in Serra dos Órgãos, Rio de Janeiro State, Brazil. Zoologia 26 (1): 97-102. 
Targino, M.; P.N. Costa \& S.P. Carvalho-E-Silla. 2009. Two new species of the Ischnocnema lactea species series from the Itatiaia highlands, southeastern Brazil (Amphibia, Anura, Brachycephalidae). South American Journal of Herpetology 4 (2): 139-150.

Van Sluys, M.; C.F.D. Rocha; F.H. Hatano; L. Boquimpani-Freitas \& R.V. Marra. 2004. Anfíbios da restinga de Jurubatiba: composição de espécies e História Natural, p. 165-178. In: C.F.D. Rocha; F.R. Scarano \& F.A. Esteves (Eds). Ecologia, História Natural e Conservação da Restinga do Parque Nacional de Jurubatiba. São Carlos, Ed. Rima, 374p.

Van Sluys, M.; C.A.G. Cruz; D. Vrcibradic; H.R. Silva; M. AlmeidaGomes \& C.F.D. Rocha. 2009. Anfíbios nos remanescentes florestais de Mata Atlântica no Estado do Rio de Janeiro, p. 175-182. In: H.G. Bergallo; E.C.C. Fidalgo; C.F.D. Rocha; M.C. Uzêda; M.B. Costa; M.A.S. Alves; M. Van Sluys; M.A. Santos; T.C.C. Costa \& A.C.R. Cozzolino (Eds). Estratégias e Ações para a Conservação da Biodiversidade no Estado do Rio de Janeiro. Rio de Janeiro, Instituto Biomas, 344p.

Vrcibradic, D.; F.H. Hatano; C.F.D. Rocha \& M. Van Sluys. 2006. Geographic Distribution. Phyllodytes luteolus. Herpetological
Review 37 (4): 489.

Vrcibradic, D.; M. Almeida-Gomes; M. Van Sluys \& C.F.D. Rocha. 2008. Amphibia, Anura, Hylodes charadranaetes, Ischnocnema octavioi, and Euparkerella cochranae: Distribution extension. Check List 4 (1): 103-106.

Vrcibradic, D.; C.V. Ariani; M. Van Sluys \& C.F.D. Rocha. 2010. Amphibia, Leptodactylidae, Paratelmatobius mantiqueira: Distribution extension. Check List 6 (1): 1-2.

Weber, L.N.; M. Bilate; L.S. Procaci \& S.P. Silva. 2007. Amphibia, Anura, Hylodidae, Hylodes charadranaetes: Distribution extension and notes on advertisement calls. Check List 3 (4): 336-337.

Weber, L.N.; T. Silva-Soares \& R.O.L. Salles. 2009. Amphibia, Anura, Hylidae, Hypsiboas secedens: Reassessment of type locality coordinates and distribution extension. Check List 5 (2): 218-221.

Weber, L.N.; V.K. Verdade; R.O.L. Salles; A. Fouquet \& S.P. CarvaLHO-E-SILVA. 2011. A new species of Cycloramphus Tschudi (Anura: Cycloramphidae) from the Parque Nacional da Serra dos Órgãos, Southeastern Brazil. Zootaxa 2737: 19-33.

Submitted: 20.IV.2010; Accepted: 13.VII.2011.

Editorial responsibility: Mauricio O. Moura

Appendix. Voucher specimens of the species recorded in the present study deposited at the Museu Nacional, Rio de Janeiro (MNRJ).

Aplastodiscus arildae: MNRJ 51867, MNRJ 53879, MNRJ 60199; Aplastodiscus leucopygius: MNRJ 60200, MNRJ 64589-91; Bokermannohyla carvalhoi: MNRJ 51489, MNRJ 66150-1, MNRJ 66154; Bokermannohyla circumdata: MNRJ 51490, MNRJ 56487-94; Brachycephalus didactylus: MNRJ 56514-15; Brachycephalus garbeanus: MNRJ 57124, MNRJ 57293; Brachycephalus sp.: MNRJ 51470-1, MNRJ 5650413, MNRJ 56516, MNRJ 66543; Dendrophriniscus cf. brevipollicatus: MNRJ 58300-2, MNRJ 60700; Dendropsophus minutus: MNRJ 51875; Flectonotus fissilis: MNRJ 56942, MNRJ 67316; Flectonotus sp.: MNRJ 62845, MNRJ 64646; Gastrotheca albolineata: MNRJ 56528; Gastrotheca ernestoi: MNRJ 57129; Haddadus binotatus: MNRJ 51866, MNRJ 55479; Holoaden pholeter: MNRJ 51475 (holotype), MNRJ 53482-3 (paratypes), MNRJ 57242; Hylodes charadranaetes: MNRJ 59032-3, MNRJ 59061-2, MNRJ 59174-6, MNRJ 60159-61, MNRJ 68693-6; Hypsiboas polytaenius: MNRJ 51873-4; Ischnocnema erythromera: MNRJ 51868-72; Ischnocnema guentheri: MNRJ 57207, MNRJ 57288, MNRJ 60172, MNRJ 60178-9, MNRJ 66566; Ischnocnema cf. holti: MNRJ 51474, MNRJ 57251, MNRJ 57308-9, MNRJ 67511-3, MNRJ 68690, MNRJ 68940; Ischnocnema parva: MNRJ 55455, MNRJ 55480, MNRJ 66344-5; Ischnocnema sp. (gr. lactea): MNRJ 60164-6; Myersiella microps: MNRJ 66222-3; Proceratophrys boiei: MNRJ 64582; Proceratophrys melanopogon: MNRJ 51360-3, MNRJ 64229; Rhinella gr.crucifer: MNRJ 51857-8; Scinax albicans: MNRJ 51488, MNRJ 61212; Scinax flavoguttatus: MNRJ 51481-2; Scinax fuscovarius: MNRJ 57298; Scinax cf. obtriangulatus: MNRJ 66346; Scinax cf. perereca: MNRJ 65771-2; Scinax v-signatus: MNRJ 53880-1, MNRJ 56495-6; Zachaenus parvulus: MNRJ 55452-4. 